\title{
As diversas vidas de Zé Bebelo*
}

MARCOANTÔNIO TAVARESCOELHO

A FORÇA E A SINGULARIDADE dos episódios, dos acontecimentos e da trajetória da vida social na região do São Francisco refletem-se diretamente na literatura. E sta se impõe entre nós por várias razões, entre as quais o contraste que estabelece com o cotidiano tão "normal" dos grandes centros, como São Paulo e Rio de J aneiro. Pois o que se origina ou o que tem seu lastro no mundo sanfranciscano apresenta situações inusitadas e fascinantes. I sto porque nesse campo da cultura aparecem elementos mágicos que emergem com força em conseqüência de hábitos, costumes, crendices e do imaginário da região do São Francisco.

N ão por acaso, Guimarães Rosa começa advertindo: "Sertão, é isto, o senhor sabe: tudo incerto, tudo certo" (GS, p. 121). O u "sertão é onde manda quem é forte com as astúcias. D eus mesmo, quando vier, que venha armado! $E$ bala é um pedacinho de metal..." (GS, p. 17)

Então, nos relatos do acontecido na região do Velho Chico, difícil é separar o que foi real do que brotou da imaginação. E vice-e-versa. Por isso ali tem vigência uma lei: muitos imbróglios não podem ser deslindados e explicados.

A prova disto está no GrandeSertão: Veredas. D epois de quase cinco décadas de seu lançamento, quando vão se acumulando as reedições da obra-prima, inúmeras são as análises que vêm a lume para tentar elucidar questões lançadas pelo romancista.

As controvérsias são incontáveis, mas al gumas o piniões vão ganhando consenso entre os especial istas. U ma delas é a de que G uimarães R osa retirou personagens, fatos, comportamentos, entrechoques e to da a riqueza da sua narrativa daquele manancial que ele recolheu em suas minuciosas pesquisas no noroeste e no norte de M inas, no coração do Velho Chico. Claro, corrompeu palavras, deu a elas mais sabor, aqui ou acolá. Provocou uma revolução na sintaxe, para incorporar a fala oral sanfranciscana. M as sabia os limites de sua recriação, daí sua veracidade e legitimidade.

A quase totalidade dos personagens do romance já foi identificada. Assim explica Levínio Castilho, que procedeu a um cuidadoso exame dessa questão: "várias estórias contadas por antigos moradores identificaram coronéis e jagunços assemelhados aos personagens Riobaldo, H ermógenes, Ricardão, T itão Pas-

* N otas preliminares para um livro, em elaboração pelo autor, sobre o São Francisco. 
sos, Joaozinho Bem-bem, heróis dos sertões de Corinto, Paracatu, Sussuarão, I tacambira e J anuária, magnificamente fotografadas por Rosa" ${ }^{1}$.

Tal indicação é confirmada pela análise do ensaísta Alan Viggiano ao nos asseverar que "Guimarães Rosa não inventou sequer um nome, em toda a toponímia utilizada na saga de Riobaldo Tatarana. Esta convicção emergiu da elevada percentagem - constatada na pesquisa - de nomes de rios, lagos, córregos, veredas, vilas, povoados, cidades, que têm existência real no Norte de M inas, Sudeste de Goiás e Sudoeste da Bahia e foram utilizados por Rosa na fantástica aventura vivida por Riobaldo e seus cabras naquele pedaço de chão" 2 .

o fascínio em torno desse livro vem mobilizando pessoas abalizadas no mundo das letras, a fim de serem esclarecidos fatos narrados no Grande Sertão, desde que muitos e muitos leitores anseiam por mais dados sobre os personagens do livro e a respeito de fatos descortinados pelo romancista.

E aqui entra uma questão que pode desatar um caudaloso inquérito sobre um personagem central do romance, porque sua "fotografia" foi só revelada pelas metades: a identificação de Zé Bebelo e o resgate da incrível e intrigante história da pessoa real que foi "apresentada" sob o nome de Zé Bebelo.

Assim, estamos diante de um "caso" extremamente curioso: nas entrelinhas da novela magistral há outra "novela" (ou uma novela que nada tem de ficção, pois trata-se de um conjunto de dados verdadeiramente acontecidos), mas que Guimarães Rosa nos ficou devendo, sabe D eus por quê?

Vamos ao imbróglio. M as, por capítulos.

Em primeiro lugar, Zé B ebelo, junto com Riobaldo Tartarana e D iadorim, formam a tríade que está no âmago, no centro do romance de G uimarães Rosa. Alguns traços básicos, sintetizados por Alan Viggiano, definem Zé Bebelo. "É um misto de cangaceiro e aspirante político que, financiado pelo governo, resolvera 'pôr ordem naqueles sertões'" 3 . Ele fora abandonado por Riobaldo, que, depois, incorporado aos jagunços contrários, Ihe dará combate. $\mathrm{N}$ as primeiras refregas, os homens de Zé Bebelo, ajudados pelos soldados do governo, vão vencendo e jogando os cangaceiros para o norte.

A seguir, os cangaceiros derrotam o bando de Zé Bebelo. Riobaldo arma então um estratagema para salvar seu líder da morte, gritando que J oca Ramiro recomendara pegá-lo vivo. Zé Bebelo é capturado e julgado, mas é absolvido pelos cangaceiros liderados por J oca Ramiro.

Em sendo assim, Zé Bebelo é forçado a se afastar do cangaço, embora depois retorne, com o intuito de vingar a morte de seu amigo Joca Ramiro. Seguem-se vários combates, sendo os jagunços fustigados duplamente pelos soldados e pelo bando de H ermógenes - os inimigos mortais, pois assassinaram J oca Ramiro, o pai de D iadorim. Aí tem lugar a grande jogada de Zé B ebelo: ele manda escrever cartas às autoridades. Recados que seriam levados por mensageiros noturnos, escapando entre inimigos, com grandes riscos, mas informando sobre a localização dos cangaceiros. 
Revela-se, pois, o liame entre Zé B ebelo e os soldados, o que acabou sendo útil aos companheiros de Riobaldo. Este assume a chefia do bando, Zé Bebelo desiste da fama de jagunço e some no mundo. Ao final, fere-se o combate decisivo contra os comparsas de $\mathrm{H}$ ermógenes, alcançando-se o que motivava a luta matar os que assassinaram J oca Ramiro. M as, oh céus!, chega-se à tragédia total. D iadorim é morto em combate.

\section{N o mundo real, quem foi R otílio?}

Segundo capítulo. Q uem era o personagem que no livro ganhou o nome de Zé Bebelo?

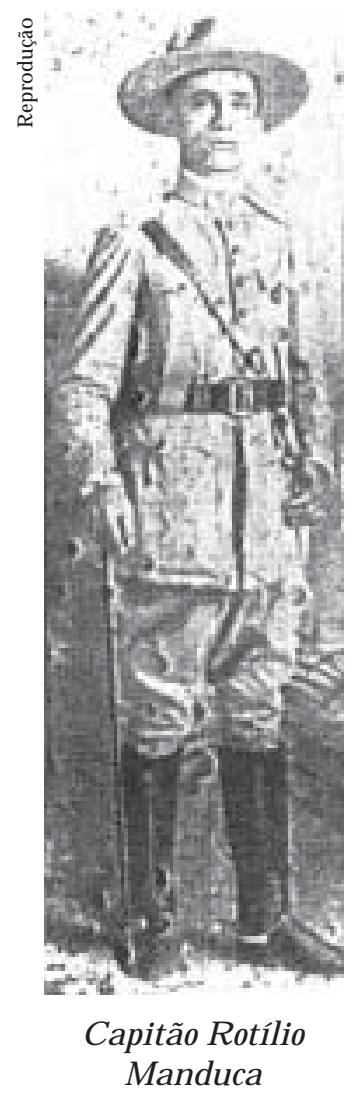

D e acordo com uma pesquisa feita por L evínio C astilho e endossada por Saul M artins, antropólogo, especialista em folclore e professor da U FM G, "Zé Bebelo é a encarnação de Rotílio M anduca" ${ }^{4}$. Afirmação cabal e conclusiva, emanada de duas pessoas de J anuária, amadurecidas por anos de estudos das coisas do São Francisco. D e saída, convém dizer que o nome de Rotílio M anduca aparece no Grande Sertão, nas páginas 341, 346 e 368*. Na segunda referência, o romancista de Cordisburgo praticamente descreve a figura de Rotílio, como se pode constatar ao se examinar as duas fotografias de Rotílio, publicadas por Saul Martins no livro A ntônio Dó ${ }^{5}$.

C abe então a suspeita de que Guimarães R osa queria deixar alguns indícios que permitiriam, aos mais curiosos, descobrir a identidade de Zé Bebelo. Lê-se no Grande Sertão:

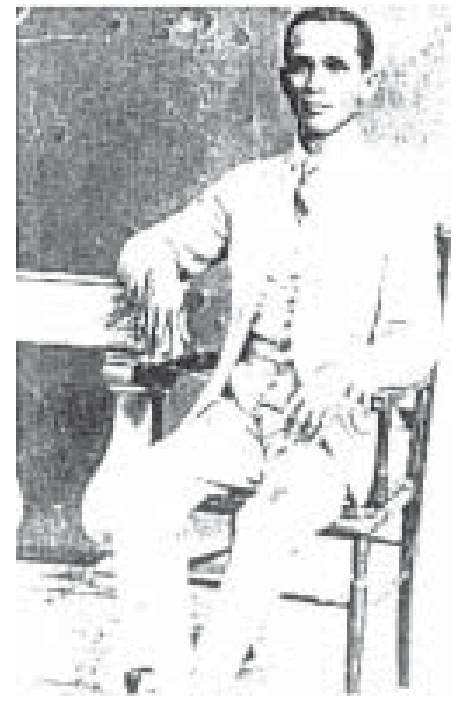

R otílio M anduca: "vestido ci dadão"

Aquele - sequinho, espigadinho, vestido cidadão, com mãozinhas pequenas, pezinhos - e do ar sempre assustado constantemente. D ele sozinho, o que se diz: umas duzentas mortes! Conheceu, o senhor? No barranco do São Francisco - o coronel Rotílio M anduca - em sua Fazenda Baluarte! (GS, p. 346).

Agora, os fatos.

Rotílio de Souza M anduca nasceu em 1885, em Remanso, na Bahia, cidade hoje submersa pelas águas da represa de Sobradinho. Lá estudou e certamente concluiu o segundo grau, tornando-se um autodidata a partir de então. Se-

* Ascitações de GrandeSer tão: Veredas foram baseadasna12a a J oséO lympio E ditora, 1978. 
guindo as informações do professor Saul M artins, ele era filho do casal José Bertoldo $\mathrm{M}$ anduca e I nácia de L oiola $\mathrm{M}$ anduca.

A fama e a valentia de Rotílio começa quando ele era ainda um garoto. "Conta-se que seu genitor, um barqueiro, se juntara a uma concubina, com quem passou a morar, na sua barca de frete, assim desprezando a esposa, faltando mesmo com a responsabilidade de sustento da família" ${ }^{6}$. U m certo dia, ante a difícil situação financeira em que se encontrava, com seus irmãos passando fome, Rotílio pega a carabina do pai e mata o vigia da barca, ferindo seu genitor, levando este a reassumir seu compromisso com a família.

A trajetória assombrada de Rotílio segue por caminhos espantosos. É um dos mais valentes jagunços de que se teve notícia; hábil no uso do punhal, da faca e do trabuco. Tinha como objetivo limpar o sertão dos jagunços usando suas próprias artimanhas. A parece como um líder, sendo mobilizado para a luta contra a Coluna Prestes e para apaziguar o sertão, a serviço do então presidente da República, Artur Bernardes. U ma fotografia atesta sua condição de oficial comissionado da Polícia M ilitar de M inas Gerais.

Virgílio de M ello Franco, um dos principais líderes do movimento que derrubou a República Velha, em seu livro O utubro de1930, informa que a conspiração revolucionária no sertão da Bahia era articulada "por intermédio dos chefes Rotílio M anduca e J oão D uque" 7 .

A fama de Rotílio como "justiceiro" correu pelo São Francisco, e lhe eram atribuídas cerca de duzentas mortes. Por isso, sua lenda mantém-se "viva até hoje no Vale do São Francisco, nos sertões do A baeté, J anuária, I tacambira, C oração de J esus e Pirapora" 8 .

M as Rotílio tinha outra "vida". D espia seu gibão de couro de sertanejo e envergava ternos de linho da alta sociedade carioca, a fim de circular livremente no Rio de Janeiro e Belo H orizonte. Sobre essa "identidade" de Rotílio M anduca, Alberto Deodato deixou um relato surpreendente. Antes de inserir esse longo mas indispensável registro, énecessário, porém, apresentar o perfil desse depoente.

Alberto $D$ eodato $M$ aia Barreto nasceu em Sergipe, imigrou para B elo $\mathrm{H} \mathrm{o-}$ rizonte, na década de 1920, para formar-se em D ireito e projetar-se como jornalista, escritor e político. Conseguiu plenamente tudo isso. $\mathrm{N}$ a capital mineira, brilhava no fórum como advogado. Considerado um autêntico liberal, foi eleito vereador em Belo H orizonte, antes do golpe de Estado de 1937. Foi meu professor na famosa Faculdade de Direito de M inas Gerais. Q uando sobreveio a redemocratização do país, conseguiu um mandato de deputado federal pela U D N , tornando-se um de seus líderes nacionais.

Eis o que o professor Alberto $D$ eodato escreveu a respeito de sua convivência, no Rio de Janeiro, com Rotílio M anduca:

Em 1919, uma tarde, eu estava na Fol ha, de M edeiros de Albuquerque, de que era redator. Procurou-me um senhor moreno fechado. A presentou-se-me. 
- Sou o coronel Rocha, de Brasília, amigo de Rotílio. Ele soube de sua formatura e me pediu lhe entregasse esse presente...

Era o anel de grau. U m lindo anel, que sempre usei. Três meses quem me entra pelo quarto a dentro? O Rotílio de carne e osso. M oreno queimado. D e óculos pretos. Bem vestido. M agro e ágil. Eu morava, agora, na rua da Lapa, 56. U m quarto de fundo, com duas camas: a minha ea do C iro Vieira da C unha. Enfiou a mala no meu quarto. Vinha passar uns dias comigo.

- M as eu não tenho cama ...

- Armo a rede...

E arranjou-se numa rede atravessada. $\mathrm{N}$ ão podia ficar em hotel. $\mathrm{N}$ ão por falta de dinheiro. M as porque vinha de um tiroteio no São Francisco. Viajou léguas e léguas de batina e óculos pretos, a cavalo. Trazia enorme apetrecho de disfarce: batina, barba, bigode, o diabo.

D e noite para o dia desapareceu, levando tudo que era seu U m ano depois volta. Vai para um bom hotel. Livre da perseguição. Vai me visitar. [...] Foi aí que conheceu $M$ anoel Bandeira, C iro eRibeiro C outo. $O$ fraco desse sertanejo era a admiração pelos intelectuais. De uma feita, passo pela Brahma. E quem vejo - Rotílio M anduca, almoçando com M edeiros e Albuquerque, a quem eu havia apresentado na véspera. Com mais de um mêsno Rio de J aneiro, Rotílio ficou amigo do M inistro Ataulpho de Paiva. $\mathrm{N}$ ão sei como [... ${ }^{9}$

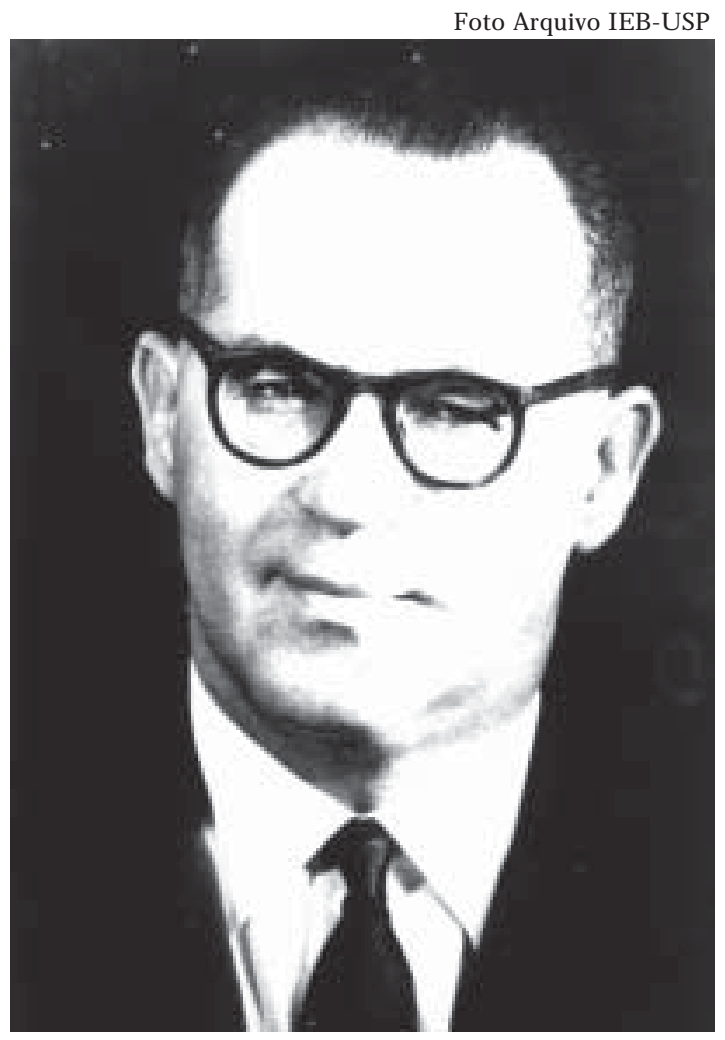

O escritor Guimarães R osa
O estudante Alberto D eodato conheceu Rotílio em Pirapora, passagem obrigatória para quem transitava pelo São Francisco, do Nordeste para M inas Gerais. Os dois tornaram-se amigos. No Rio de Janeiro, R otílio freqüentava rodas políticas e intelectuais, lia os clássicos e fazia versos. M as seu hábitat era o sertão do São Francisco. Jamais poderia romper o cordão umbilical que o prendia à realidade sertaneja. Ali nasceu e ali encontraria seu fim.

M orreu na cidade da Barra, num camarote do vapor "Wenceslau Braz", da Cia. N avegação M ineira do São Francisco, no dia 3 de maio de 1930, navio comandado por Pedro M anduca, seu irmão. A família deste espalhou-se pela região sanfranciscana, inclusive por Paracatu. 
Rotílio foi esfaqueado quando dormia numa rede, balançada pelas águas do Velho Chico. 0 rio que o embalou em sua infância, que abriu os caminhos para sua ascensão, como líder de jagunços e de justiceiros; o rio que o aproximou dos poderosos e da intelectualidade; o mesmo rio, enfim, que embalaria a rede que seria a sua mortalha.

Assim morreu Rotílio M anduca.

Até que renasceu para a eternidade no corpo de Zé Bebelo, no Grande Sertão: Veredas. Seu epitáfio pode ser encontrado na literatura de cordel:

Rotílio, cabra valente

$M$ ais danado e inteligente

Q ue o São Francisco já viu;

$M$ ais ligeiro que a piranha,

Foi o cabra de mais manha

Q ue mulher de homem pariu.

Autoria anônima (apud Saul M artins)

N otas

1 Levínio C astilho, "Pesquisa sobre G rande Sertão: Veredas. Q uem éZé B ebelo", texto datilografado, Belo H orizonte, $\mathrm{s} / \mathrm{d}$.

2 Alan Viggiano, "Itinerário de Riobaldo Tatarana", Brasília, IN L/ Comunicação/ M ec, 1974, p. 21.

3 I dem, p. 50.

4 L evínio Castilho, op. cit., p. 7.

5 Saul M artins, A ntônio Dó, 3ạ ed., Belho H orizonte, SESC/ M G, 1997.

6 I dem, p. 80.

7 Levínio Castilho, op. cit., p. 11.

8 I dem, p. 10.

9 Alberto Deodato, "Roteiro da Lapa ... e outros roteiros", Belo H orizonte, I tatiaia, 1960, pp. 24-25.

M arco A ntônio Tavares $C$ oel ho, jornalista, é editor-executivo da revista Estudos A vançados. É autor de $\mathrm{H}$ erança de um sonho: Memórias de um comunista (Record) e R io das Velhas M emória edesafios (Paz e Terra).

Texto recebido e aceito para publicação em 25 de setembro de 2003. 